\title{
Autophagy-related gene 12 (ATG12) is a novel determinant of primary resistance to HER2-targeted therapies: Utility of transcriptome analysis of the autophagy interactome to guide breast cancer treatment
}

\author{
Sílvia Cufí ${ }^{1,2}{ }^{*}$, Alejandro Vazquez-Martin ${ }^{1,2},{ }^{*}$, Cristina Oliveras-Ferraros $^{1,2, *}$, Bruna \\ Corominas-Faja ${ }^{1,2}$, Ander Urruticoechea ${ }^{3}$, Begoña Martin-Castillo, ${ }^{2,4}$ Javier A. \\ Menendez ${ }^{1,2}$ \\ ${ }^{1}$ Metabolism and Cancer Group, Translational Research Laboratory, Catalan Institute of Oncology-Girona (ICO-Girona) \\ 2 Molecular Oncology, Girona Biomedical Research Institute (IDIBGi) \\ 3 Department of Medical Oncology, Breast Unit, Catalan Institute of Oncology (ICO)-Hospital Universitari de Bellvitge- \\ Bellvitge Research Institute (IDIBELL) \\ ${ }^{4}$ Clinical Research Unit, Catalan Institute of Oncology-Girona (ICO-Girona) \\ * denotes equal contribution
}

Correspondence to: Javier A. Menendez, email: jmenendez@iconcologia.net

Keywords: Autophagy; ATG genes; HER2; trastuzumab; lapatinib

Received: November 07, 2012, Accepted: November 15, 2012, Published: November 17, 2012

Copyright: () Cufi et al. This is an open-access article distributed under the terms of the Creative Commons Attribution License, which permits unrestricted use, distribution, and reproduction in any medium, provided the original author and source are credited.

ABSTRACT:

The autophagic process, which can facilitate breast cancer resistance to endocrine, cytotoxic, and molecularly targeted agents, is mainly regulated at the posttranslational level. Although recent studies have suggested a possible transcriptome regulation of the autophagic genes, little is known about either the analysis tools that can be applied or the functional importance of putative candidate genes emerging from autophagy-dedicated transcriptome studies. In this context, we evaluated whether the constitutive activation of the autophagy machinery, as revealed by a transcriptome analysis using an autophagy-focused polymerase chain reaction (PCR) array, might allow for the identification of novel autophagy-specific biomarkers for intrinsic (primary) resistance to HER2-targeted therapies. Quantitative real-time PCR (qRT-PCR)-based profiling of 84 genes involved in autophagy revealed that, when compared to trastuzumab-sensitive SKBR3 cells, the positive regulator of autophagic vesicle formation ATG12 (autophagy-related gene 12) was the most differentially upregulated gene in JIMT1 cells, a model of intrinsic cross-resistance to trastuzumab and other HER1/2-targeting drugs. An analysis of the transcriptional status of ATG12 in > 50 breast cancer cell lines suggested that the ATG12 transcript is commonly upregulated in trastuzumab-unresponsive HER2-overexpressing breast cancer cells. A lentiviral-delivered small hairpin RNA stable knockdown of the ATG12 gene fully suppressed the refractoriness of JIMT1 cells to trastuzumab, erlotinib, gefitinib, and lapatinib in vitro. ATG12 silencing significantly reduced JIMT1 tumor growth induced by subcutaneous injection in nude mice. Remarkably, the outgrowth of trastuzumabunresponsive tumors was prevented completely when trastuzumab treatment was administered in an ATG12-silenced genetic background. We demonstrate for the first time the usefulness of low-density, autophagy-dedicated qRT-PCR-based platforms for monitoring primary resistance to HER2-targeted therapies by transcriptionally screening the autophagy interactome. The degree of predictive accuracy warrants further investigation in the clinical situation. 


\section{INTRODUCTION}

Although molecular drugs that specifically target one or several members of the HER signaling network can affect the expression and/or activation status of the HER2 oncoprotein, accumulating evidence suggests that the actual repercussions of HER2-targeting drugs (e.g., the anti-HER 2 monoclonal antibody trastuzumab or the dual HER1/HER2 tyrosine kinase inhibitor lapatinib) for tumor growth inhibition are closely related to the ability of these drugs to efficiently impede specific signaling pathways downstream of HER2 [1-8]. The identification of these pathways and whether they are operative before, during, and/or after treatment with HER2-inhibiting drugs might enable individual therapeutic decisions to be based on tumor biology rather than on basic histopathological data alone [9-23]. Autophagy (from the Greek autos, itself, and phagein, to eat) is a constitutive catabolic pathway that mediates both non-specific and targeted sequestration of cellular organelles and other macromolecules, which permits the degradation of cellular components in lysosomes and the recycling of bioenergetic metabolites [24-26]. The activation of autophagy might constitute a molecular mechanism that, beyond HER2 expression status in breast carcinoma cells, may accurately reflect the reliance of HER2 gene-amplified breast carcinomas on HER2-driven signaling [27-29].

Previous studies have linked autophagy to both tumor-suppressive (i.e., autophagy defects that predispose individuals to tumor development) and tumor-promoting functions (i.e., autophagy activation promotes survival under stress, including cytotoxic chemotherapy) [3035]. Of note, HER 2 signaling and responsiveness to trastuzumab appear to dynamically interact with both the tumor-suppressive and tumorigenic roles of autophagy. The loss of ATG6/Beclin1, one of the earliest characterized mammalian autophagy genes that suggested a tumor suppression function for autophagy in certain mouse models of mammary oncogenesis [36-39], has been suggested to contribute to HER2 gene amplification as well as to alterations in PI3K and PTEN, two crucial downstream effectors of HER2 [40]. Because the main predictors of trastuzumab activity in both pre-clinical and clinical settings are HER2 gene amplification and activation of the PI3K pathway, defined as PTEN loss and/or PIK3CA mutation [41-44], the loss of ATG6/ Beclin1 might function as a positive predictor of the tumor response to HER2-targeted therapies. Defective autophagy can therefore lead to enhanced cell death of HER2-positive cancer cells bearing competent apoptosis or senescence pathways upon challenge with HER2 inhibiting drugs [28]. However, we have added trastuzumab to the growing list of molecularly targeted therapeutics that activate the prosurvival function of autophagy as part of their mechanism of action [27]. Autophagic cell death, also referred to as active cell death II [APDC II], has been suggested to occur in response to extreme autophagic degradation triggered upon exposure to several cancer therapies [4547], but it is not an obligatory outcome of trastuzumabactivated autophagy in a trastuzumab-responsive model of HER2 gene-amplified breast carcinoma cells. Our studies additionally confirmed that the hyperactivation of basal autophagy was causally related to the acquisition of secondary resistance to trastuzumab [27]. Thus, "protective autophagy" causally enabled HER2 geneamplified breast carcinoma cells to optimally grow for several months in the presence of clinically relevant concentrations of trastuzumab. The exploration of the cytoprotective effects of autophagy in breast cancer cells subjected to the pharmacologically mediated depletion of growth factor receptor signaling by mono-HER1 (i.e., gefitinib, cetuximab), mono-HER2 (i.e., trastuzumab), and dual HER1/HER2 (i.e., lapatinib) inhibitors has confirmed that enhanced autophagic activity can contribute to more efficient maintenance of cancer cell resistance to HER targeting drugs [48-51]. However, a crucial aspect of this process that has remained unexplored is the possibility that HER2 gene-amplified breast carcinoma cells might also exploit the cytoprotective role of autophagy to escape from HER2-targeted therapies ab initio.

It is well recognized that the autophagic process is mainly regulated at the post-translational level. However, a growing body of evidence has started to suggest that autophagy might also be regulated at the transcriptional level. We now have several methods and tools for the analysis of the autophagic flux and post-translational modifications of autophagy proteins [52]. Unfortunately, little is known about the analysis tools that can be applied to explore changes in the expression of autophagy genes or about the functional importance of putative candidate genes emerging from autophagy-dedicated transcriptome studies. In this context, we first assessed the utility of an autophagy-focused polymerase chain reaction (PCR) array to identify novel autophagy-specific gene biomarkers for intrinsic (primary) resistance to trastuzumab in HER2 gene-amplified breast cancer cells that naturally exhibit bona fide primary resistance to HER-targeted therapies $[12,13,17,53-55]$. Second, using molecular biology approaches we unambiguously validated whether the autophagy genes differentially expressed in trastuzumabrefractory breast carcinoma cells functionally predicted the primary response to the growth-inhibitory and anti-tumoral effects of trastuzumab. When employing pre-clinical models of trastuzumab-refractory HER2-overexpressing breast cancer cultures and xenografts, we were able to confirm that the transcriptional screening of the autophagy interactome can accurately identify autophagic pathway genes that operate as a primary mechanism of trastuzumab resistance in breast carcinoma cells. 


\section{RESULTS}

Autophagy-focused PCR arrays indicate ATG12 as a candidate gene for primary (inherent) resistance to trastuzumab. We first explored whether there is a programmed series of genetic events that control the autophagic flux that could accompany de novo refractoriness to trastuzumab in HER2 gene-amplified breast carcinoma cells. RNAs from trastuzumabresponsive SKBR3 cells, a widely employed in vitro tumor model characterized by naturally occurring HER 2 gene amplification, HER2 receptor protein overexpression, and HER2-dependency for cell proliferation and survival $[18,56,57]$, and trastuzumab-refractory JIMT1 cells, a
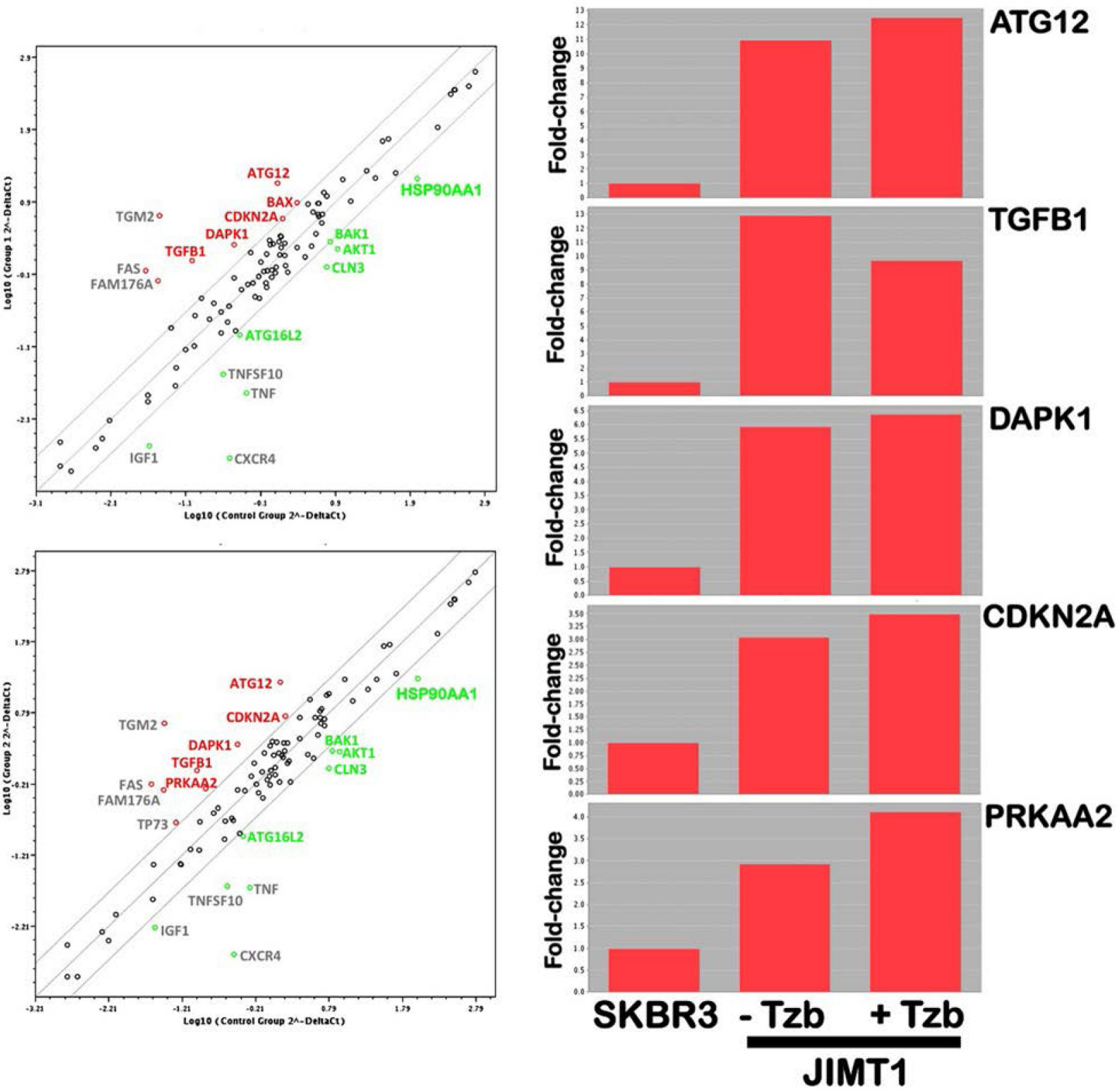

Figure 1: Analysis of autophagy genes in trastuzumab-refractory breast cancer cells. Left. Total RNA from trastuzumabsensitive SKBR3 and trastuzumab-refractory JIMT-1 cells was characterized in technical triplicates using the Autophagy RT ${ }^{2}$ Profiler PCR Array as per the manufacturer's instructions (SABiosciences; http://www.sabiosciences.com/rt_pcr_product/HTML/PAHS-084A.html). Representative scatter plots of the difference ( $\geq 2$-fold; green and red symbols indicate downregulation and upregulation $v s$. expression levels in SKBR3 cells, respectively) in relative transcript abundance of 84 key genes involved in autophagy are shown. Grey symbols denote the fold-change results to be validated with a sufficient number of biological replicates [i.e., fold-change results may have greater variations if the $p$-value $>0.05$, or the $p$-value for the fold-change is either unavailable or relatively high $(p>0.05)]$ or that are uninterpretable because the gene's average threshold cycles were either not determined or were greater than the defined cut-off value (default 35) in both samples. Total. The transcript abundance of selected autophagy-related genes were calculated using the delta $\mathrm{Ct}$ method and presented as fold-change vs. basal expression in trastuzumab-sensitive SKBR3 cells. 
HER2 gene-amplified cell line established from a ductal carcinoma pleural metastasis of a 62-year-old patient who did not respond to trastuzumab treatment ab initio [53-55], were evaluated by quantitative real-time PCR (qRT-PCR) to evaluate the expression of 84 key genes involved in autophagy (Fig. 1). When we imposed a two-fold change in mRNA expression level as the cut-off requirement to determine significant regulatory effects on autophagyrelated genes, the autophagy suppressor BAK1 (BCL2antagonist/killer 1; $\downarrow 3$-fold), the chaperone HSP90AA1 (Heat Shock Protein $90 \mathrm{kDa}$ alpha [cytosolic], class $A$ member $1 ; \downarrow 6$-fold), the mTOR-related negative regulator of autophagy AKT1 ( $\downarrow 6$-fold), and the endosomal/ lysosomal membrane protein-coding gene CLN3 (CeroidLipofuscinosis, Neuronal 3; $\downarrow 6$-fold) were identified as down-regulated in trastuzumab-unresponsive JIMT1 cells compared to trastuzumab-responsive SKBR3 cells. The metabolic master rheostat protein PRKAA2 (AMP- activated Protein Kinase catalytic subunit alpha-2; $\uparrow 3-$ fold), the retinoblastoma-related senescence/autophagy marker CDKN2A/p16 (cyclin-dependent kinase inhibitor 2 ; $\uparrow 3$-fold), the autophagy stimulator DAPK1 (DeathAssociated Protein Kinase 1; $\uparrow 6$-fold), the multifunctional cytokine TGF 1 1 (Transforming Growth Factor- $\beta 1$; 13-fold), and the essential autophagy gene ATG12 (Autophagy-related 12 homolog (S. cerevisiae); $\uparrow 11$-fold) were significantly up-regulated in trastuzumab-refractory JIMT1 cells. Trastuzumab exposure, while incapable of influencing the proliferation of JIMT1 cells, slightly enhanced the differential overexpression of the autophagyrelated genes PRKAA2, CDKN2A/p16,DAPK1 and ATG12 (Fig. 1).

ATG12 is differentially up-regulated in HER2 geneamplified breast carcinoma cells that exhibit primary (inherent) resistance to trastuzumab. To exclude JIMT1 cell line-specific effects and to further confirm that the
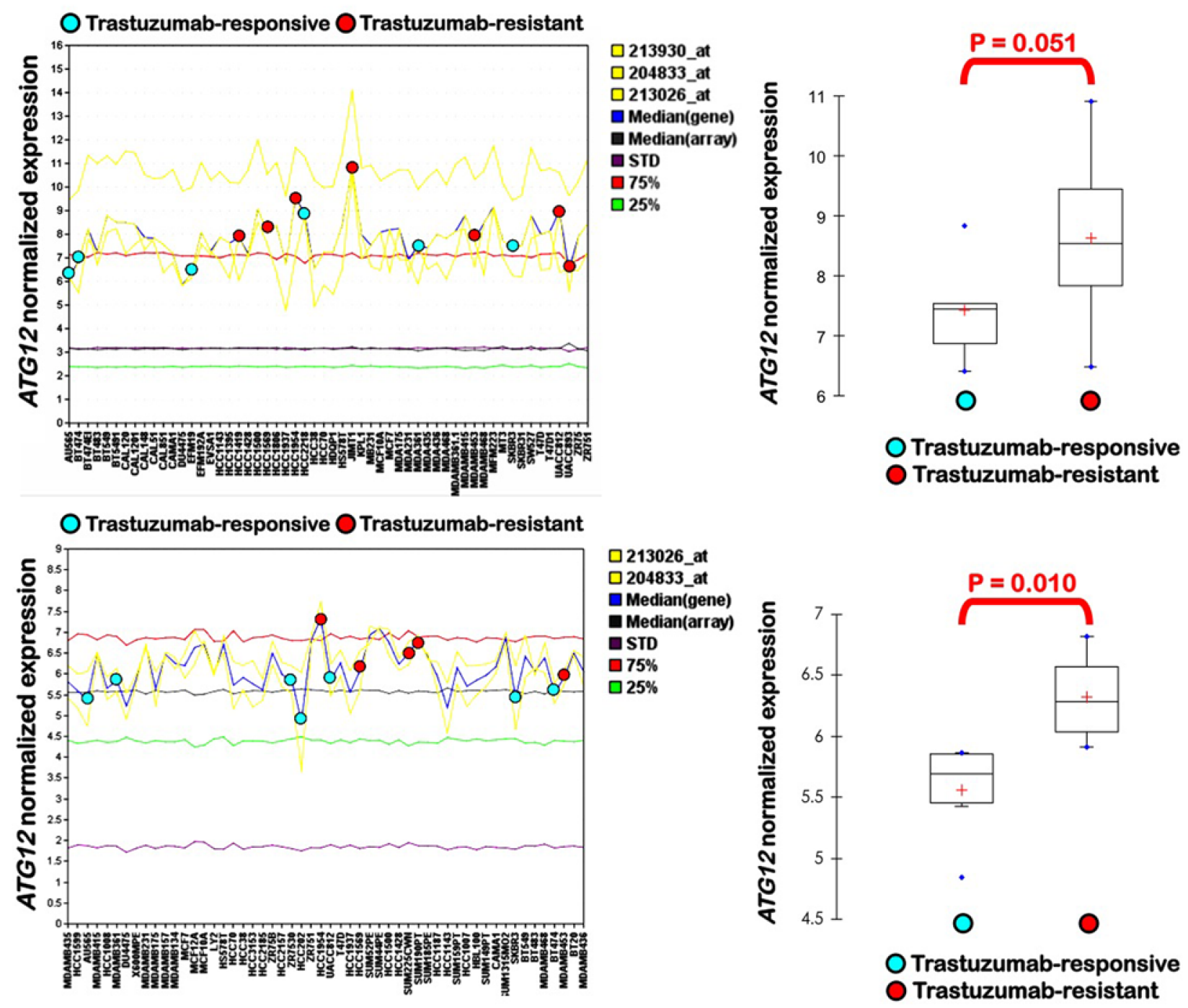

Figure 2: Differential expression of ATG12 in trastuzumab-responsive and trastuzumab-resistant breast cancer cell lines. Distribution of $A T G 12$ gene expression in trastuzumab-responsive and trastuzumab-resistant breast cancer cell lines across the Adai data set (top) and the Neve's data set (bottom). 

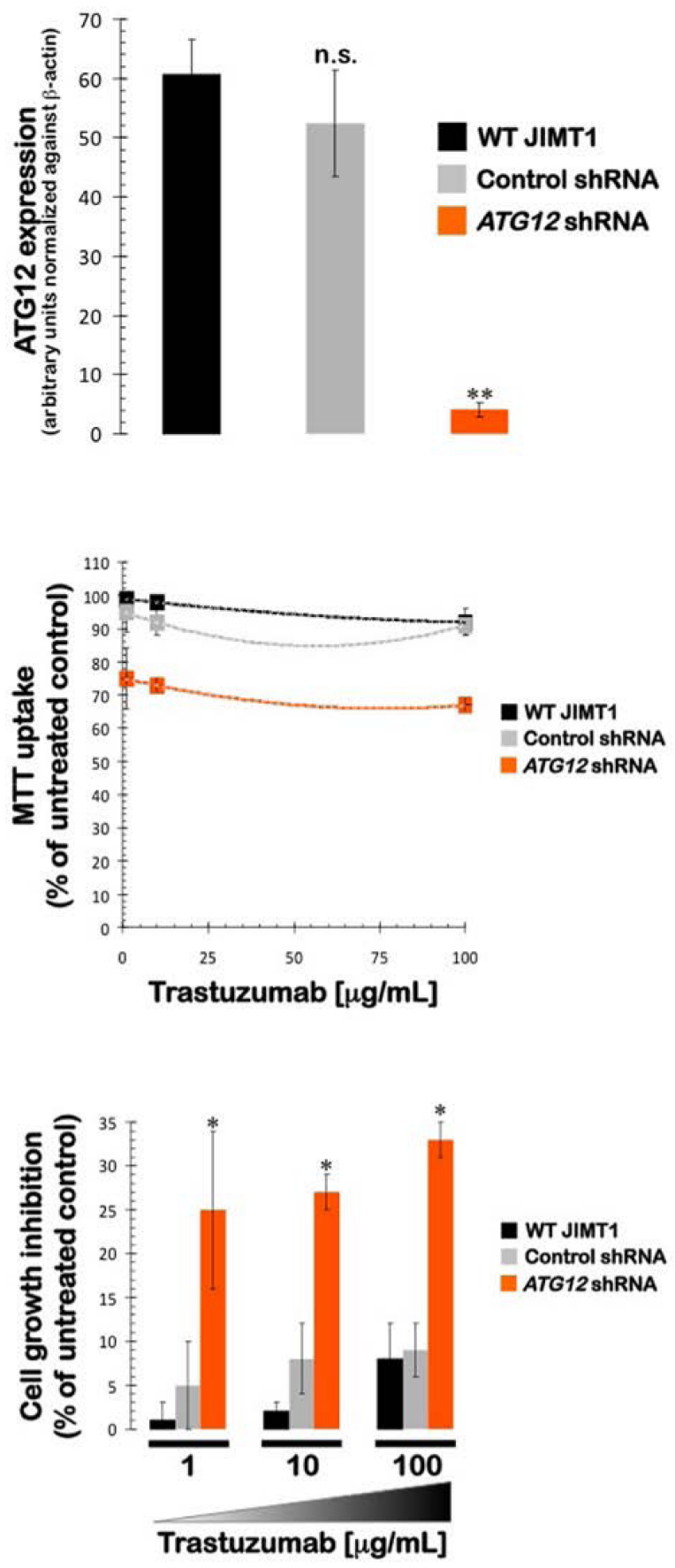

Figure 3: Impact of shRNA-driven genetic ablation of ATG12 on the efficacy of the anti-HER2 monoclonal antibody trastuzumab (Herceptin) in vitro. The metabolic status of JIMT1 parental cells, control shRNAJIMT1 cells, and ATG12 shRNA-JIMT1 cells treated with graded concentrations trastuzumab was evaluated using MTTbased cell viability assays, followed by the generation of doseresponse graphs depicting the \% of untreated cells (untreated control cells $=100 \%$ cell viability). The results are presented as the means (columns) and $95 \%$ confidence intervals (bars) of three independent experiments performed in triplicate. [n.s. not significant; * $\mathrm{P}<0.05]$ differential overexpression of the ATG12 gene might correlate with breast cancer cell phenotypes of primary (inherent) resistance to trastuzumab, we took advantage of the ROCK online interface, a publicly accessible portal that enables the rapid integration of breast cancer functional and molecular profiling datasets [58]. We analyzed the transcriptional profile of the ATG12 gene across the Adai (GSE1090) gene expression dataset, which includes 56 breast cancer cell lines, and across the Neve's gene expression data set, which includes 54 widely used breast cancer cell lines [59]. The HER2-positive breast cancer cell lines were classified as trastuzumab-sensitive or trastuzumab-refractory based on the data from the literature. We then compared the normalized expression data for ATG12 among trastuzumab-sensitive (blue dots in Fig. 2) and trastuzumab-refractory (red dots in Fig. 2) cell lines. When the expression status of $A T G 12$ was interrogated in the Adai data set, an increasing trend in mean ATG12 mRNA expression values was observed in the trastuzumab-refractory group, which proved to be almost statistically significant ( $\mathrm{P}=0.051$; Fig. 2$)$. This trend reached statistical significance when analyzing the differences in ATG12 gene expression between the trastuzumab-refractory and the trastuzumab-sensitive groups in the Neve's data set ( $\mathrm{P}=0.010$; Fig. 2$)$.

Small hairpin RNA-driven stable knockdown of ATG12 sensitizes JIMT1 cells to trastuzumab and eliminates cross-resistance to HER1/HER2 tyrosine kinase inhibitors in vitro. To molecularly establish a causal role of ATG12-driven autophagy in the de novo resistance of HER2 gene-amplified breast cancer cells to trastuzumab, we employed a lentivirus-mediated stable knockdown of the ATG12 gene. To control for any off-target effects of short hairpin (sh)RNA transduction, control (negative) lentiviral particles were also used strictly in parallel. First, we determined if the expression of ATG12 was significantly silenced in JIMT1 cells that were stably transduced with ATG12-shRNAs. Lysates were produced from JIMT1 cell cultures stably expressing shRNAs that were designed to recognize and reduce the expression of ATG12 as well as from JIMT1 cells stably transduced with an empty vector (control shRNA). Immunoblotting analyses confirmed that ATG12 protein expression was reduced to almost undetectable levels ( $>95 \%$ reduction) in JIMT1 cells that were lentivirally transduced with ATG12 shRNAs compared to parental cells transduced with empty vector (see Ref. 60). All subsequent experiments were performed with these stable cell lines, which were termed control-shRNA/JIMT1 and ATG12-shRNA/JIMT1.

MTT-based cell viability assays were performed to evaluate the ability to reduce cell growth in JIMT1 cells before and after the stable knockdown of ATG12. Nontransduced JIMT1 parental cells, control-shRNA/JIMT1 cells, and ATG12-shRNA/JIMT1 cells were treated with various concentrations of trastuzumab for five days. We failed to obtain half-maximal inhibitory concentrations 
$\left(\mathrm{IC}_{50}\right)$ in both the parental and control-shRNA/JIMT1 cells, thus confirming the robust resistance of JIMT1 cells to trastuzumab-mediated cytotoxicity (Fig. 3). ATG12-shRNA/JIMT1 cells, however, demonstrated a significantly enhanced sensitivity to trastuzumab at concentrations as low as $1 \mu \mathrm{g} / \mathrm{mL}$. Thus, the insignificant levels of cell viability loss induced by trastuzumab in both the parental and control-shRNA/JIMT1 cells (i.e., 1\% reduction at $1 \mu \mathrm{g} / \mathrm{mL}$ trastuzumab and $8 \%$ reduction at $100 \mu \mathrm{g} / \mathrm{mL}$ trastuzumab, respectively) were augmented by up to 25 -fold (i.e., from $25 \%$ reduction at $1 \mu \mathrm{g} / \mathrm{mL}$ trastuzumab to $33 \%$ reduction at $100 \mu \mathrm{g} / \mathrm{mL}$ trastuzumab, respectively) in ATG12-shRNA/JIMT1 cells (Fig. 3).

Because we recently demonstrated that the $\mathrm{IC}_{50}$ values for the small molecule HER1/HER2 TKIs gefitinib, erlotinib, and lapatinib were drastically higher (up to 40-fold) in trastuzumab-refractory JIMT1 cells than in trastuzumab-sensitive SKBR3 cells [17], we sought to evaluate whether the specific knockdown of ATG12 was sufficient to eliminate the inherent cross-resistance of JIMT1 cells to HER targeting drugs. Remarkably, the $\mathrm{IC}_{50}$ values for gefitinib, erlotinib, and lapatinib were drastically reduced as a result of ATG12 gene silencing (Fig. 4). The gefitinib $\mathrm{IC}_{50}$ value decreased from $8.0 \pm 1.5$ $\mu \mathrm{mol} / \mathrm{L}$ and $7.8 \pm 1 \mu \mathrm{mol} / \mathrm{L}$ in parental and control-shRNA/ JIMT1 cells, respectively, to $1.85 \pm 0.7 \mu \mathrm{mol} / \mathrm{L}$ in ATG12shRNA/JIMT1 cells (i.e., $\approx 4$-fold decrease). The erlotinib $\mathrm{IC}_{50}$ value decreased from $5.0 \pm 1.0 \mu \mathrm{mol} / \mathrm{L}$ and $4.5 \pm 1.0$ $\mu \mathrm{mol} / \mathrm{L}$ in parental and control-shRNA/JIMT1 cells, respectively, to $0.5 \pm 0.2 \mu \mathrm{mol} / \mathrm{L}$ in ATG12-shRNA/JIMT1 cells $\left(\right.$ i.e., $\approx 10$-fold decrease). The lapatinib $\mathrm{IC}_{50}$ value decreased from $7.0 \pm 1.0 \mu \mathrm{mol} / \mathrm{L}$ and $7.5 \pm 1.0 \mu \mathrm{mol} / \mathrm{L}$ in parental and control-shRNA/JIMT1 cells, respectively, to $0.7 \pm 0.4 \mu \mathrm{mol} / \mathrm{L}$ in ATG12-shRNA/JIMT1 cells (i.e., $\approx 10$ fold decrease). Of note, the sensitizing effect of $A T G 12$ knockdown was restricted to HER targeting drugs because the growth inhibitory responses of ATG12-shRNA/JIMT1 cells to various cytotoxic molecules (i.e., doxorubicin, 5-fluorouracil, cisplatin, vinorelbine, and paclitaxel) remained unaltered (data not shown).

ATG12 knockdown reduces tumor growth and sensitizes trastuzumab-resistant xenografts to trastuzumab. The effects of the specific ATG12 gene knockdown on tumor growth were investigated in vivo in a JIMT1 xenograft animal model (Fig. 4). Compared to the untreated control group $\left(2266 \pm 228 \mathrm{~mm}^{3}\right)$, nine weeks of treatment with trastuzumab $(5 \mathrm{mg} / \mathrm{kg} /$ week $)$ failed to prevent tumor growth by the parental JIMT1 cells; the mean tumor size reached volumes as large as $1556 \pm 298 \mathrm{~mm}^{3}$ in the presence of trastuzumab. However, compared to the mean xenograft tumor size in both the shRNA-control and trastuzumab-treated groups, the mean tumor size of the ATG12-shRNA/JIMT1 cells was smaller $\left(858 \pm 121 \mathrm{~mm}^{3}\right)$. Remarkably, when the ATG12shRNA/JIMT1 xenografts were treated with trastuzumab weekly, the mean tumor size was drastically reduced to
$46 \pm 21 \mathrm{~mm}^{3}$, thus demonstrating that the sensitivity of trastuzumab-refractory JIMT1 xenografts to trastuzumab increased dramatically when the cells were depleted of the autophagy driver ATG12. Whereas trastuzumab treatment reduced the tumor volume of ATG12-expressing JIMT1 xenografts 63 days post-injection by approximately $30 \%$,
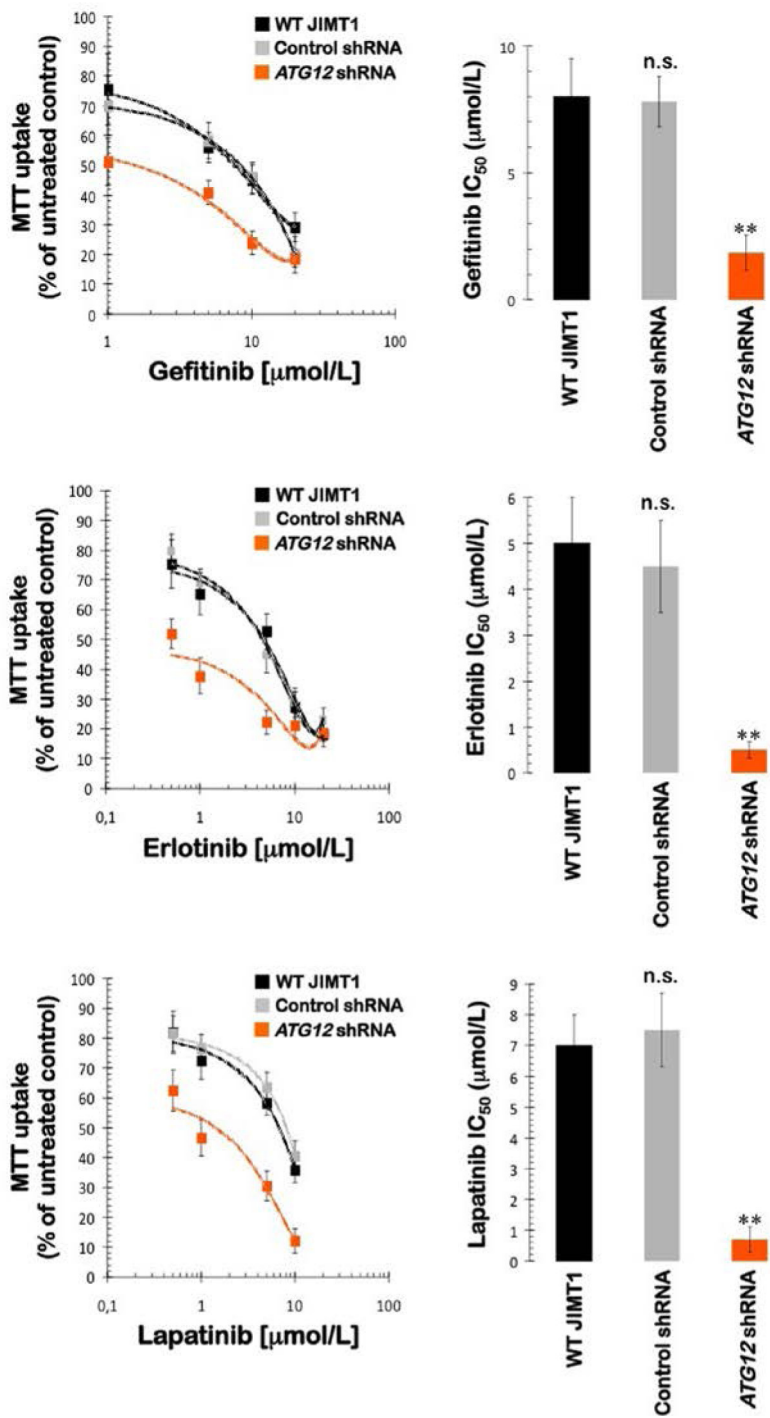

Figure 4: Impact of shRNA-driven genetic ablation of ATG12 on the efficacy of HER1/2-tyrosine kinase inhibitors in vitro. Left panels. The metabolic status of JIMT1 parental cells, control shRNA-JIMT1 cells, and ATG12 shRNA-JIMT1 cells treated with graded concentrations of erlotinib, gefitinib, and lapatinib was evaluated using MTTbased cell viability assays, followed by the generation of doseresponse graphs depicting the \% of untreated cells (untreated control cells $=100 \%$ cell viability). The results are presented as the means (columns) and $95 \%$ confidence intervals (bars) of three independent experiments performed in triplicate. Right panels. The degree of sensitivity of JIMT1 parental cells, control shRNA-JIMT1 cells, and ATG12 shRNA-JIMT1 cells to HER 1/2-targeting drugs is illustrated by bars representing mean $\mathrm{IC}_{50}$ values in each cell line. Error bars show standard deviations. [n.s. not significant; ** $\mathrm{P}<0.005$ ] 
trastuzumab exposure reduced the tumor volume of ATG12-silenced JIMT1 xenografts by an impressive 98\% over the same treatment time (Fig. 5).

\section{DISCUSSION}

We have previously reported that HER2overexpressing breast cancer cells that have been chronically exposed to the anti-HER2 monoclonal antibody trastuzumab exhibit a bona fide up-regulation of the basal autophagic activity that efficiently operates to protect breast cancer cells from the growth-inhibitory effects of trastuzumab [27]. Our working model proposed that enhanced autophagosome formation and the subsequent catabolic function of autophagy flux actively contribute to the survival of HER2-dependent breast cancer and facilitate the rapid development of resistance to trastuzumab in cells that initially respond to treatment. Consequently, the blockade of the autophagic machinery should significantly help to prevent or retard the appearance of acquired (secondary) resistance to trastuzumab in HER2 gene-amplified breast carcinoma cells [27, 28]. However, whether HER2-positive breast cancer cells might also exploit the cytoprotective role of autophagy to escape from HER2-targeted therapies $a b$ initio was unexplored. Taking advantage of the HER2 gene-amplified JIMT1 cell line [17, 53-55], which inherently exhibits cross-resistance to multiple HER $1 / 2$ inhibiting drugs, we have provided evidence for the first time that one of the ubiquitin-like conjugation systems that is requisite for the formation of autophagic vesicles (i.e., ATG12) [61-66] is a novel determinant of primary resistance to HER1/2-targeted therapeutics.

In this study, we first analyzed the correlation between primary resistance to trastuzumab and the expression status of several genes that regulate distinct molecular events leading to autophagic vesicle formation [61-63, 67-70], including its initiation (e.g., beclin1) and maturation by the ATG12 (e.g., ATG12 and ATG5) and LC3 (e.g., ATG4B) conjugation systems. We demonstrated that DAPK1, TGFB1, and ATG12 are the three proautophagic genes with the highest differential up-

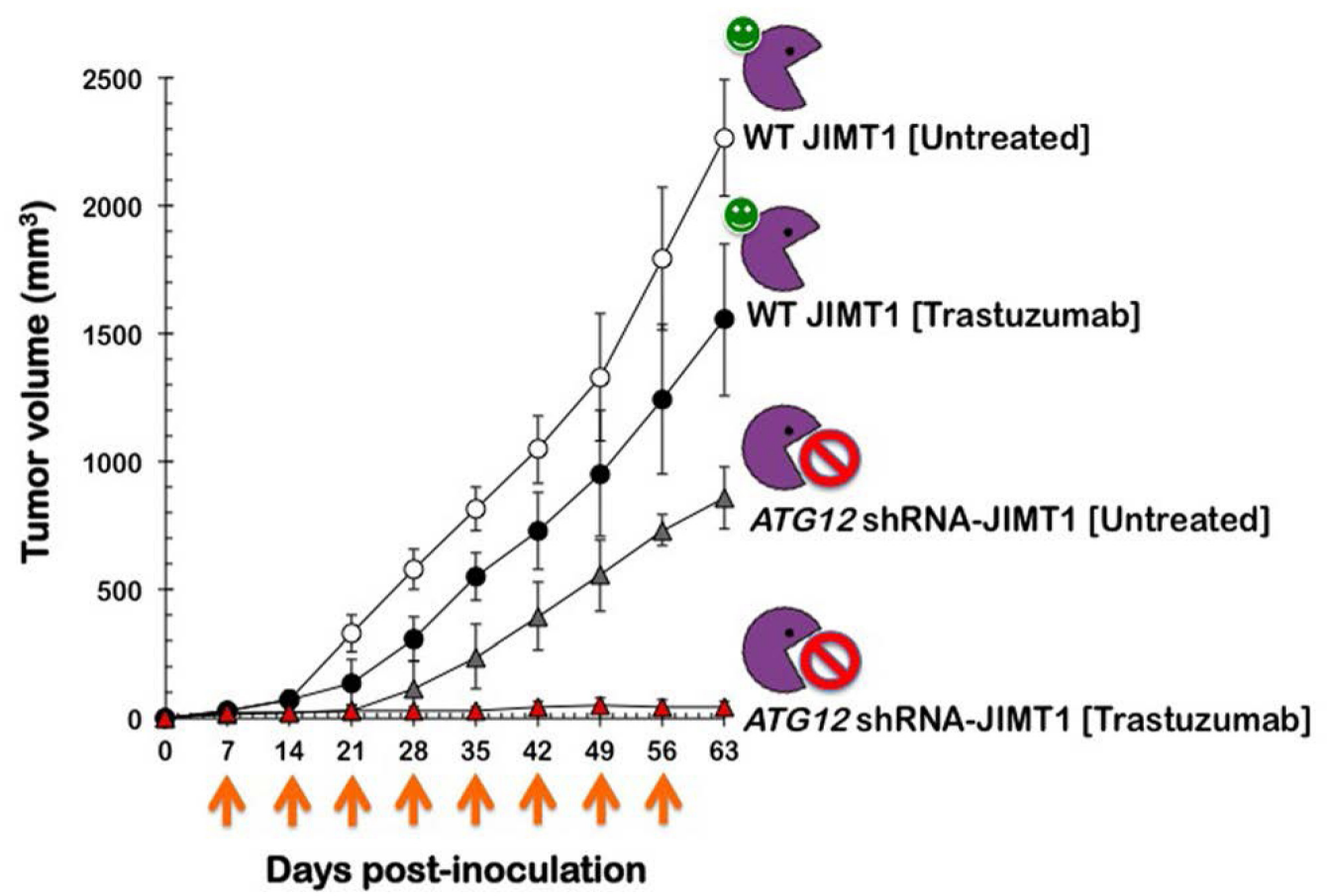

Trastuzumab [5 mg/kg/week]

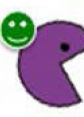

Active Autophagy

\section{(8) Deficient Autophagy}

Figure 5: Impact of shRNA-driven genetic ablation of $A T G 12$ on the efficacy of trastuzumab in vivo. Shown are the mean tumor volumes $( \pm \mathrm{SD})$ in JIMT1 and ATG12 shRNA-JIMT1 xenograft-bearing nude mice following injection with trastuzumab $(5 \mathrm{mg} / \mathrm{kg} /$ week) for nine weeks. Data from control shRNA-JIMT1 cells were superimposable with those obtained in JIMT1 parental cells and have been omitted for simplicity. 
regulation $(>5$-fold) between trastuzumab-unresponsive JIMT1 cells and trastuzumab-sensitive SKBR3 cells. The death-associated protein kinase-1 (DAPK1) induces autophagy and apoptosis through independent mechanisms [71, 72]. Autophagy induced by DAPK1 overexpression can be attenuated by knocking down expression of the microtubule-associated protein MAP1B [72], suggesting that the interaction of DAPK-1 with MAP1B, which in turn is capable of interacting with LC3, might be responsible for the DAPK-1-driven induction of autophagy. The extremely pleiotropic behavior of DAPK-1 [73] also suggests that transcriptional programs influenced by DAPK-1 might also impact the propensity of cells to undergo autophagy. TGF $\beta$, the best-characterized inducer of the epithelial-to-mesenchymal transition (EMT), has been shown to induce the accumulation of autophagosomes and the autophagic conversion of LC3 while enhancing the degradation of long-lived proteins $[74,75]$. TGF $\beta$-induced autophagy appears to contribute to the growth inhibitory and tumor suppressive effects of TGF $\beta$, in conjunction with other anti-proliferative pathways downstream of TGF $\beta$ signaling. Of note, DAPK-1 is commonly silenced in human cancers by methylation [73] and has tumor and metastasis suppressor properties. DAPK-1- and TGF $\beta$ driven autophagy, therefore, can be viewed as dual-model paradigms in which autophagy may contribute to tumor suppression early in the development of a subset of HER2 gene-amplified breast carcinomas; however, when these tumors somehow bypass the tumor suppressor activity of DAPK-1 and TGF $\beta$, autophagy would later allow the selection of invasive, mesenchymal cells with an enhanced expression of autophagic and stem cell markers. In breast cancer, the undifferentiated $\mathrm{CD} 44^{+} \mathrm{CD} 24^{-/ \text {low }}$ antigenic state commonly attributed to breast cancer subpopulations with cancer stem cell (CSC) properties is highly enriched with EMT transcriptional factors and mesenchymal markers [76-82]. Of note, our group has recently confirmed that a) $\mathrm{CD} 44^{+} \mathrm{CD} 24^{- \text {llow }}$ mesenchymal subpopulations are intrinsically unresponsive to trastuzumab [83]; b) the absence or presence of the $\mathrm{CD} 44^{+} \mathrm{CD} 24^{- \text {low }}$ mesenchymal immunophenotype is closely related to the inherent sensitivity or refractoriness of HER2-gene amplified breast carcinoma cells to trastuzumab [83], respectively; and c) the impairment of the autophagic flux by genetic means (i.e., ATG12 gene silencing) drastically decreases the number of trastuzumab-unresponsive cells bearing $\mathrm{CD} 44^{+} \mathrm{CD} 24^{-/ \text {low }}$ cell surface antigens and appears to impede the ontogeny of generating the CSC-like $\mathrm{CD} 44^{+} \mathrm{CD} 24^{-/ \text {low }}$ mesenchymal phenotype by preventing the full acquisition of a post-EMT status [60]. These findings, together with our current description that a) ATG12 overexpression is a new molecular biomarker for primary resistance to trastuzumab and b) inherent unresponsiveness to trastuzumab can be switched to sensitivity simply by depleting ATG12 notably delineates a new scenario in which primary resistance to HER2- targeted drugs can be understood in terms of HER2 geneamplified breast carcinoma cells that are intrinsically capable of generating highly autophagic, undifferentiated CD $44^{+} \mathrm{CD} 24^{- \text {/low }}$ antigenic states. Importantly, when investigating the relationship between the biological roles of autophagy in trastuzumab-mediated cancer therapy, we concluded that ATG12-related autophagic flux specifically functions as a protective cellular phenotype against HER-targeting drugs. Whereas the $\mathrm{IC}_{50}$ values for the small-molecule HER1/2 TKIs erlotinib, gefitinib, and lapatinib were drastically reduced by up to 10 -fold in response to ATG12 gene silencing, the knockdown of ATG12 failed to alter the sensitivity of JIMT1 cells to multiple cytotoxics, including doxorubicin, 5-fluorouracil, cisplatin, vinorelbine, and paclitaxel (data not shown). Autophagy addiction underlying the primary resistance of HER2 gene-amplified breast cancer cells to HER1/2 targeting therapies may depend, at least in part, on the previously unrecognized ability of autophagy to regulate a trastuzumab-unresponsive $\mathrm{CD} 44^{+} \mathrm{CD} 24^{- \text {llow }}$ mesenchymal cellular state.

Autophagy-addicted, trastuzumab-unresponsive JIMT1 cells significantly upregulated the expression of PRKAA2, the catalytic subunit of the master regulator of cellular energy homeostasis AMPK [84-86]. Cancer cells are largely unable to change their metabolic programming as a result of their oncogenic alterations [87-91], which may underlie the sensitivity of HER2-overexpressing breast cancer cells to growth factor receptor inhibitors, including trastuzumab and lapatinib. Indeed, the lapatinib-induced activation of AMPK and the consequent inhibitory effects on protein synthesis and de novo fatty acid biogenesis are lethal to HER2 gene-amplified breast carcinoma cells that are "addicted" to glycolysis [92, 93]. Lapatinib treatment seems to deprive cells of energy not only via the down-regulation of glycolysis but also by further triggering an entire cascade of metabolic events mediated by the activation of AMPK. AMPK activation ultimately results in downstream events that conserve cellular energy by inhibiting fatty acid synthesis while activating fatty acid oxidation as an alternative source of energy. Intriguingly, the ability of AMPK to coordinate the adaptive response of cellular bioenergetics to ATP depletion may also be responsible, at least in part, for the reduced sensitivity of $H E R 2$ gene-amplified breast cancer cells to HER-targeting drugs. Given that AMPK modulates the activity of crucial regulators of autophagy such as mTOR, increased expression of AMPK accompanied by the downregulation of key negative regulators of mTOR (i.e., AKT1) may aid trastuzumab-refractory breast cancer cells in mounting a protective autophagic response from a molecular perspective. The chronic elevation of AMPK and mTOR activities likely results in a shift toward catabolism, which can inherently prepare HER2-overexpressing cells to accommodate the acute bioenergetic crisis imposed by HER-targeting drugs. This 
AMPK-related metabolic scenario is likely associated with the occurrence of autophagic, trastuzumab-refractory $\mathrm{CD} 44^{+} \mathrm{CD} 24^{-/ \text {low }}$ mesenchymal immunophenotypes because treatment with metformin, a partial inhibitor of autophagy due its limited ability to strongly reduce intracellular ATP [94-96], is sufficient to efficiently kill EMT-related CD $44^{+} \mathrm{CD} 24^{- \text {-low }}$ cells and restore trastuzumab efficacy in HER2 gene-amplified breast cancer cells with primary resistance to HER1/2-targeting therapies [18, 97101].

A priori autophagic flux is a crucial feature that determines the efficacy of HER2-directed drugs $a b$ initio. Targeting autophagy addiction may be helpful in circumventing the primary resistance to HER2 targeting therapies and may potentiate the efficacy of HER2 targeting strategies currently in use in HER2-positive breast cancer patients. While ATG12 is not currently a druggable target, emerging autophagy inhibitors (e.g., Lys05, Spautin-1) that target other components of the autophagic vesicle assembly [102-104] may prove to be an effective means to circumvent primary resistance to and potentiate the efficacy of HER2-targeting strategies currently in use in HER2-positive breast cancer patients. All human clinical trials currently exploring autophagy inhibition as a therapeutic strategy employ chloroquine or its derivative hydroxychloroquine due to the long track record of safety in human patients [105-107]. However, recent studies suggest that hydroxychloroquine is not a potent autophagy inhibitor at clinically tolerable doses and that chloroquine-mediated lysosomal dysfunction sensitizes breast cancer cells to chemotherapy independent of autophagy [108]. Despite this unfavorable scenario, we are currently exploring whether chloroquine-induced inhibition of the final step in the autophagic pathway sensitizes autophagy-addicted [109], trastuzumabrefractory HER2-positive breast cancer cells to the growth inhibitory activity of trastuzumab. Preliminary evidence appears to support a valuable pre-clinical scenario in which lysosomotropic autophagy inhibitors (e.g., chloroquine and its derivatives) [105] could prove to be more effective and autophagy-specific when combined with molecularly targeted drugs (e.g., trastuzumab) whose mechanisms of action involve HER2 internalization and recycling [110-113] via chloroquine-targeted lysosomal pathway-dependent degradation.

Using very simple bioinformatics tools on wellestablished cell-based breast carcinoma models, we demonstrated for the first time the usefulness of lowdensity, autophagy-dedicated qRT-PCR-based platforms for monitoring primary trastuzumab resistance by transcriptionally screening the autophagy interactome. The autophagy qRT-PCR tool used on trastuzumab-refractory breast cancer cells allowed for the rapid and accurate identification of differentially expressed autophagy genes (e.g., ATG12) that were causally associated with intrinsic resistance to the anti-tumoral effects of the molecularly targeted anti-HER2 drugs. While our current ability to accurately measure basal autophagic flux or determine whether autophagy is activated or inhibited in patient samples (i.e., immunohistochemical- or immunoblottingbased detection of autophagic markers, such as LC3 and SQSTM1/p62) is very limited and of unproven utility in human patients, the method of analysis described here or other similar technologies involving human autophagydedicated cDNA microarrays [114], by allowing the simultaneous monitoring of the expression level of multiple autophagy genes, might provide a practical method for analyzing the impact of the autophagy interactome in the in vivo response of breast cancer tissues to anti-cancer therapies. The degree of accuracy that constitutive activation of autophagy, as revealed by a transcriptome analysis using PCR arrays, can provide to predict trastuzumab efficacy warrants further investigation in the clinical situation.

\section{METHODS}

\section{Drugs}

The EGFR (HER1)-Tyrosine Kinase Inhibitor (TKI) gefitinib (ZD1839; Iressa ${ }^{\square}$ ) was kindly provided by AstraZeneca (AstraZeneca PLC Headquarters, 15 Stanhope Gate, W1K 1LN, London, UK). The EGFR (HER1) TKI erlotinib (Tarceva ${ }^{\circledR}$ ) was a kind gift from Roche Pharmaceuticals (Neuilly sur Seine, France). The dual HER1/HER2-TKI1 lapatinib (GW572016; Tykerb $\left.{ }^{\square}\right)$ was kindly provided by GlaxoSmithKline (GSK), Corporate Environment, Health \& Safety (Brentford, Middlesex TW8 9GS, UK). Stock solutions of gefitinib, erlotinib, and lapatinib (10 $\mathrm{mmol} / \mathrm{L})$ were prepared in DMSO and stored in aliquots in the dark at $-20^{\circ} \mathrm{C}$ until use. Trastuzumab (Herceptin ${ }^{\circledR}$ ) was kindly provided by Hospital Universitari de Girona Dr. Josep Trueta Pharmacy (Girona, Spain). Trastuzumab was solubilized in bacteriostatic water for injection containing $1.1 \%$ benzyl alcohol (stock solution at $21 \mathrm{mg} / \mathrm{mL}$ ), stored at $4^{\circ} \mathrm{C}$ and used within 1 month. For experimental use, all experimental agents were prepared fresh from stock solutions and were diluted with cell growth medium. Control cells were cultured in media containing identical concentrations (v/v) as that used for test cells. The vehicle solutions had no noticeable influence on the proliferation of experimental cells.

\section{Cell lines and culture conditions.}

JIMT1 cells were obtained from the German Collection of Microorganisms and were routinely grown in Dulbecco's modified Eagle's medium (DMEM, Gibco ${ }^{\circledR}$ Cell Culture Systems) containing 10\% heat-inactivated 
fetal bovine serum (FBS, Bio-Whittaker, Inc.), 1\% L-glutamine, $1 \%$ sodium pyruvate, $50 \mathrm{U} / \mathrm{mL}$ penicillin, and $50 \mu \mathrm{g} / \mathrm{mL}$ streptomycin. The cells were maintained at $37^{\circ} \mathrm{C}$ in a humidified atmosphere with $5 \% \mathrm{CO}_{2} . \mathrm{SKBR} 3$ breast cancer cells were obtained from the American Type Culture Collection (ATCC) and were routinely grown in Improved MEM (IMEM; Biosource International) supplemented with $10 \%$ FBS and 1\% L-glutamine, $1 \%$ sodium pyruvate, $50 \mathrm{U} / \mathrm{mL}$ penicillin, and $50 \mu \mathrm{g} /$ $\mathrm{mL}$ streptomycin. Cells were maintained at $37^{\circ} \mathrm{C}$ in a humidified atmosphere of $95 \%$ air and $5 \% \mathrm{CO}_{2}$. Cells were screened periodically for Mycoplasma contamination.

\section{Lentiviral transduction.}

Pre-packaged lentiviral particles that either encoded a non-targeting shRNA (negative shRNA, sc-108080) or sequences specifically targeting the human ATG12 gene were purchased from a commercial provider (Santa Cruz Biotechnology). For viral infection of JIMT1 cells, the regular medium was replaced with culture medium containing $5 \mu \mathrm{g} / \mathrm{mL}$ polybrene (Santa Cruz Biotechnology, sc-124220). JIMT1 cells were then exposed to lentiviruses for $48 \mathrm{~h}$. Because the lentiviral shRNA particles also encode a puromycin resistance gene for transduction selection, the cells were then washed and grown in culture medium containing $10 \mu \mathrm{g} / \mathrm{mL}$ puromycin dihydrochloride (Sigma, P9620) for an additional $72 \mathrm{~h}$. The JIMT1 cells were allowed to recover and proliferate for at least 1 week before any experimental procedures and were then analyzed. To monitor the lentiviral transduction efficiency and transgene expression for the duration of the experiment, we incubated additional subsets of JIMT1 cells with lentiviral particles encoding a green fluorescence protein (GFP) reporter (sc-108084). Transduction efficiency $(>90 \%)$ was obtained as the ratio of the number of GFP-positive cells to the total number of cells from five random visual fields from three independent culture experiments.

\section{Quantitative real-time polymerase chain reaction (qRT-PCR).}

Total RNA was extracted from cell cultures using a Qiagen RNeasy kit and Qiash redder columns according to the manufacturer's instructions. One microgram of total RNA was reverse-transcribed into cDNA with a Reaction Ready ${ }^{\mathrm{TM}}$ First Strand cDNA Synthesis Kit (SABiosciences) and applied to the Human Autophagy RT $^{2}$ Profiler ${ }^{\mathrm{TM}}$ PCR Array (PAHS-084, 96-well format) following the SABiosciences RT-PCR manual. Plates were processed in an Applied Biosystems 7500 Fast RealTime PCR System Applied Biosystems, using automated baseline and threshold cycle detection. Data were interpreted with SABiosciences' web-based PCR array analysis tool.

\section{Metabolic status assessment (MTT-based cell viability assays).}

Cell viability was determined using a standard colorimetric MTT (3-4,5-dimethylthiazol-2-yl-2, 5-diphenyl-tetrazolium bromide) reduction assay. Exponentially growing cells were harvested by trypsinization, seeded at a concentration of $\sim 2.5 \times 10^{3}$ cells/200 $\mu \mathrm{L} /$ well into 96-well plates, and allowed to attach overnight. The medium was then removed, and fresh medium along with various concentrations of HER1/2 targeting drugs were added to the cultures as specified. Control cells without drugs were cultured in parallel using the same conditions with comparable media changes. Drugs were not renewed during the entire period of cell exposure. Following treatment ( 5 days), the medium was removed and replaced with fresh drug-free medium (100 $\mu \mathrm{L} /$ well), and MTT ( $5 \mathrm{mg} / \mathrm{mL}$ in PBS) was added to each well at a $1 / 10$ volume. After incubation for $2-3 \mathrm{~h}$ at $37^{\circ} \mathrm{C}$, the supernatants were carefully aspirated, $100 \mu \mathrm{L}$ of DMSO were added to each well, and the plates were agitated to dissolve the crystal product. The optical density (OD) was measured at $570 \mathrm{~nm}$ in a multi-well plate reader (Model Anthos Labtec 20101.7 reader). The cell viability effects resulting from the exposure of cells to HER1/2-targeting drugs were analyzed as percentages of the control cell absorbances, which were obtained from control wells treated with appropriate concentrations of the agents' vehicles, which were processed simultaneously. For each treatment, cell viability was evaluated as a percentage using the following equation: $\left(\mathrm{OD}_{570}\right.$ of treated sample/OD ${ }_{570}$ of untreated sample) x 100 . Breast cancer cell sensitivity to HER1/2-targeting drugs was expressed in terms of the concentration of drug required to decrease cell viability by $50 \%$ ( $\mathrm{IC}_{50}$ value). Because the percentage of control absorbance was considered to be the surviving fraction of cells, the $\mathrm{IC}_{50}$ value was defined as the concentration of HER1/2-targeting drug that produced a $50 \%$ reduction in the control absorbance (by interpolation), respectively. The degree of sensitization to HER1/2-targeting drugs by shRNA-driven silencing of ATG12 was evaluated by dividing the $\mathrm{IC}_{50}$ values of the JIMT1 parental cells by those obtained in control-shRNA/ JIMT1 cells or ATG12-shRNA/JIMT1 cells.

\section{Xenograft studies.}

To produce xenografts, approximately $5 \times 10^{6}$ JIMT1 parental cells, control-shRNA/JIMT1 cells or ATG12-shRNA/JIMT1 cells were injected subcutaneously into the dorsal flanks of female athymic nude mice (four to five weeks old, 23 to 25 g; Harlan Laboratories, France). The animals were randomized into two groups, with five 
animals in each group: control (vehicle) and trastuzumabtreated. Trastuzumab (5 mg/kg) was administered intraperitoneally (i.p.) once per week. The mice were weighed once per week after dosing, the tumor sizes were measured daily with electronic calipers, and the tumor volumes were calculated with the following formula: volume $\left(\mathrm{mm}^{3}\right)=$ length $\mathrm{x}$ width ${ }^{2} \mathrm{x} 0.5$. The experiments were approved by the Institutional Animal Care and Use Committee (IACUC) of the Institut d'Investigació Biomèdica de Bellvitge (IDIBELL; Animal Use Protocol \#6302 authorized by the Animal Experimental Commission of the Catalan Government, Barcelona, Spain).

\section{ACKNOWLEDGEMENTS}

This work was financially supported by the Instituto de Salud Carlos III (Ministerio de Sanidad y Consumo, Fondo de Investigación Sanitaria (FIS), Spain, grants CP05-00090, PI06-0778 and RD06-0020-0028), the Fundación Científica de la Asociación Española Contra el Cáncer (AECC, Spain), and the Ministerio de Ciencia e Innovación (SAF2009-11579, Plan Nacional de I+D+ I, MICINN, Spain). Alejandro Vazquez-Martin received a Sara Borrell post-doctoral contract (CD08/00283, Ministerio de Sanidad y Consumo, Fondo de Investigación Sanitaria -FIS-, Spain). Sílvia Cufí received a research fellowship (Formación de Personal Investigador, FPI) from the Ministerio de Ciencia e Innovación (MICINN, Spain).

\section{CONFLICT OF INTEREST}

The authors of this manuscript have no conflicts of interest to declare.

\section{REFERENCE}

1. Nahta R, Yu D, Hung MC, Hortobagyi GN, Esteva FJ. Mechanisms of disease: understanding resistance to HER2targeted therapy in human breast cancer. Nat Clin Pract Oncol. 2006;3:269-280.

2. Chen FL, Xia W, Spector NL. Acquired resistance to small molecule ErbB2 tyrosine kinase inhibitors. Clin Cancer Res. 2008;14:6730-6734.

3. Spector NL, Blackwell KL.Understanding the mechanisms behind trastuzumab therapy for human epidermal growth factor receptor 2-positive breast cancer. J Clin Oncol. 2009;27:5838-5847.

4. Arteaga CL, Sliwkowski MX, Osborne CK, Perez EA, Puglisi F, Gianni L. Treatment of HER2-positive breast cancer: current status and future perspectives. Nat Rev Clin Oncol. 2011;9:16-32.

5. Wong H, Leung R, Kwong A, Chiu J, Liang R, Swanton $\mathrm{C}$, Yau T. Integrating molecular mechanisms and clinical evidence in the management of trastuzumab resistant or refractory HER-2 metastatic breast cancer. Oncologist. 2011;16:1535-1546.

6. Gajria D, Chandarlapaty S. HER2-amplified breast cancer: mechanisms of trastuzumab resistance and novel targeted therapies. Expert Rev Anticancer Ther. 2011;11:263-275.

7. Garrett JT, Arteaga CL. Resistance to HER2-directed antibodies and tyrosine kinase inhibitors: mechanisms and clinical implications. Cancer Biol Ther. 2011;11:793-800.

8. Stern HM. Improving treatment of HER2-positive cancers: opportunities and challenges. Sci Transl Med. 2012;4:127rv2.

9. Vazquez-Martin A, Oliveras-Ferraros C, Colomer R, Brunet J, Menendez JA. Low-scale phosphoproteome analyses identify the mTOR effector p70 S6 kinase 1 as a specific biomarker of the dual-HER1/HER2 tyrosine kinase inhibitor lapatinib (Tykerb) in human breast carcinoma cells. Ann Oncol. 2008;19:1097-1109.

10. Vázquez-Martín A, Oliveras-Ferraros $\mathrm{C}$, del Barco S, Martín-Castillo B, Menéndez JA. mTOR inhibitors and the anti-diabetic biguanide metformin: new insights into the molecular management of breast cancer resistance to the HER2 tyrosine kinase inhibitor lapatinib (Tykerb). Clin Transl Oncol. 2009;11:455-459.

11. Martin-Castillo B, Dorca J, Vazquez-Martin A, OliverasFerraros C, Lopez-Bonet E, Garcia M, Del Barco S, Menendez JA. Incorporating the antidiabetic drug metformin in HER2-positive breast cancer treated with neo-adjuvant chemotherapy and trastuzumab: an ongoing clinical-translational research experience at the Catalan Institute of Oncology. Ann Oncol. 2010;21:187-189.

12. Oliveras-Ferraros C, Vazquez-Martin A, Martin-Castillo B, Cufí S, Del Barco S, Lopez-Bonet E, Brunet J, Menendez JA. Dynamic emergence of the mesenchymal CD44(pos) CD24(neg/low) phenotype in HER2-gene amplified breast cancer cells with de novo resistance to trastuzumab (Herceptin). Biochem Biophys Res Commun. 2010;397:2733.

13. Oliveras-Ferraros C, Vazquez-Martin A, Martin-Castilló B, Pérez-Martínez MC, Cufí S, Del Barco S, Bernado L, Brunet J, López-Bonet E, Menendez JA. Pathway-focused proteomic signatures in HER2-overexpressing breast cancer with a basal-like phenotype: new insights into de novo resistance to trastuzumab (Herceptin). Int $\mathrm{J}$ Oncol. 2010;37:669-678.

14. Steelman LS, Chappell WH, Abrams SL, Kempf RC, Long J, Laidler P, Mijatovic S, Maksimovic-Ivanic D, Stivala F, Mazzarino MC, Donia M, Fagone P, Malaponte G, Nicoletti F, Libra M, Milella M, Tafuri A, Bonati A, Bäsecke J, Cocco L, Evangelisti C, Martelli AM, Montalto G, Cervello M, McCubrey JA. Roles of the Raf/MEK/ERK and PI3K/ PTEN/Akt/mTOR pathways in controlling growth and sensitivity to therapy-implications for cancer and aging. Aging (Albany NY). 2011;3:192-222.

15. Davies AH, Dunn SE. YB-1 drives preneoplastic 
progression: Insight into opportunities for cancer prevention. Oncotarget. 2011;2:401-406.

16. Oliveras-Ferraros C, Fernández-Arroyo S, Vazquez-Martin A, Lozano-Sánchez J, Cufí S, Joven J, Micol V, FernándezGutiérrez A, Segura-Carretero A, Menendez JA. Crude phenolic extracts from extra virgin olive oil circumvent de novo breast cancer resistance to HER1/HER2-targeting drugs by inducing GADD45-sensed cellular stress, G2/M arrest and hyperacetylation of Histone H3. Int J Oncol. 2011;38:1533-1547.

17. Oliveras-Ferraros C, Vazquez-Martin A, Cufí S, TorresGarcia VZ, Sauri-Nadal T, Barco SD, Lopez-Bonet E, Brunet J, Martin-Castillo B, Menendez JA. Inhibitor of Apoptosis (IAP) survivin is indispensable for survival of HER2 gene-amplified breast cancer cells with primary resistance to HER1/2-targeted therapies. Biochem Biophys Res Commun. 2011;407:412-419.

18. Vazquez-Martin A, Oliveras-Ferraros C, Del Barco S, Martin-Castillo B, Menendez JA. The anti-diabetic drug metformin suppresses self-renewal and proliferation of trastuzumab-resistant tumor-initiating breast cancer stem cells. Breast Cancer Res Treat. 2011;126:355-364.

19. Adams JR, Schachter NF, Liu JC, Zacksenhaus E, Egan SE. Elevated PI3K signaling drives multiple breast cancer subtypes. Oncotarget. 2011;2:435-447.

20. Chappell WH, Steelman LS, Long JM, Kempf RC, Abrams SL, Franklin RA, Bäsecke J, Stivala F, Donia M, Fagone P, Malaponte G, Mazzarino MC, Nicoletti F, Libra M, Maksimovic-Ivanic D, Mijatovic S, Montalto G, Cervello M, Laidler P, Milella M, Tafuri A, Bonati A, Evangelisti C, Cocco L, Martelli AM, McCubrey JA. Ras/Raf/MEK/ ERK and PI3K/PTEN/Akt/mTOR inhibitors: rationale and importance to inhibiting these pathways in human health. Oncotarget. 2011;2:135-164.

21. McCubrey JA, Steelman LS, Chappell WH, Abrams SL, Montalto G, Cervello M, Nicoletti F, Fagone P, Malaponte G, Mazzarino MC, Candido S, Libra M, Bäsecke J, Mijatovic S, Maksimovic-Ivanic D, Milella M, Tafuri A, Cocco L, Evangelisti C, Chiarini F, Martelli AM. Mutations and Deregulation of Ras/Raf/MEK/ERK and PI3K/PTEN/ Akt/mTOR Cascades. Oncotarget. 2012;3:954-987.

22. McCubrey JA, Steelman LS, Chappell WH, Abrams SL, Franklin RA, Montalto G, Cervello M, Libra M, Candido S, Malaponte G, Mazzarino MC, Fagone P, Nicoleti F, Bäsecke J, Mijatovic S, Maksimovic-Ivanic D, Milella M, Tafuri A, Chiarini F, Evangelisti C, Cocco L, Martelli AM. Ras/Raf/MEK/ERK and PI3K/PTEN/Akt/mTOR Cascade Inhibitors: How Mutations Can Result in Therapy Resistance and How to Overcome Resistance. Oncotarget. 2012 Oct 20. [Epub ahead of print]

23. Aurisicchio L, Marra E, Roscilli G, Mancini R, Ciliberto G. The promise of anti-ErbB3 monoclonals as new cancer therapeutics. Oncotarget. 2012;3:744-758.

24. He C, Klionsky DJ. Regulation mechanisms and signaling pathways of autophagy. Annu Rev Genet 2009; 43:67-93.
25. Klionsky DJ, Emr SD. Autophagy as a regulated pathway of cellular degradation. Science 2000; 290:1717-1721.

26. Lum JJ, DeBerardinis RJ, Thompson CB. Autophagy in metazoans: cell survival in the land of plenty. Nat Rev Mol Cell Biol 2005; 6:439-448.

27. Vazquez-Martin A, Oliveras-Ferraros C, Menendez JA. Autophagy facilitates the development of breast cancer resistance to the anti-HER2 monoclonal antibody trastuzumab. PLoS One. 2009;4:e6251.

28. Vazquez-Martin A, Cufí S, Oliveras-Ferraros C, MartinCastillo B, Del Barco S, López-Bonet E, Menendez JA. Expression status of the autophagy-regulatory gene ATG6/ BECN1 in ERBB2-positive breast carcinomas: bypassing ERBB2-induced oncogenic senescence to regulate the efficacy of ERBB2-targeted therapies. Genes Chromosomes Cancer. 2011;50:284-290.

29. Hurvitz SA, Hu Y, O’Brien N, Finn RS. Current approaches and future directions in the treatment of HER2-positive breast cancer. Cancer Treat Rev. 2012 May 31. [Epub ahead of print]

30. Mathew R, Karantza-Wadsworth V, White E. Role of autophagy in cancer. Nat Rev Cancer. 2007;7:961-967.

31. White E. Deconvoluting the context-dependent role for autophagy in cancer. Nat Rev Cancer. 2012;12:401-410.

32. Yang ZJ, Chee CE, Huang S, Sinicrope FA. The role of autophagy in cancer: therapeutic implications. Mol Cancer Ther. 2011;10:1533-1541.

33. Janku F, McConkey DJ, Hong DS, Kurzrock R. Autophagy as a target for anticancer therapy. Nat Rev Clin Oncol. 2011;8:528-539.

34. Eng $\mathrm{CH}$, Abraham RT. The autophagy conundrum in cancer: influence of tumorigenic metabolic reprogramming. Oncogene. 2011; 30:4687-4696.

35. Zhou S, Zhao L, Kuang M, Zhang B, Liang Z, Yi T, Wei Y, Zhao X. Autophagy in tumorigenesis and cancer therapy: Dr. Jekyll or Mr. Hyde? Cancer Lett. 2012;323:115-127.

36. Jin S, White E. Role of autophagy in cancer: management of metabolic stress. Autophagy 2007; 3:28-31.

37. Karantza-Wadsworth V, Patel S, Kravchuk O, Chen G, Mathew R, Jin S, White E. Autophagy mitigates metabolic stress and genome damage in mammary tumorigenesis. Genes Dev. 2007;21:1621-1635.

38. Mathew R, Kongara S, Beaudoin B, Karp CM, Bray K, Degenhardt K, Chen G, Jin S, White E. Autophagy suppresses tumor progression by limiting chromosomal instability. Genes Dev. 2007;21:1367-1381.

39. Mathew R, White E. Why sick cells produce tumors: the protective role of autophagy. Autophagy 2007; 3:502-505.

40. Negri T, Tarantino E, Orsenigo M, Reid JF, Gariboldi M, Zambetti M, Pierotti MA, Pilotti S. Chromosome band $17 q 21$ in breast cancer: significant association between beclin 1 loss and HER2/NEU amplification. Genes Chromosomes Cancer. 2010;49:901-909.

41. Berns K, Horlings HM, Hennessy BT, Madiredjo M, 
Hijmans EM, Beelen K, Linn SC, Gonzalez-Angulo AM, Stemke-Hale K, Hauptmann M, Beijersbergen RL, Mills GB, van de Vijver MJ, Bernards R. A functional genetic approach identifies the PI3K pathway as a major determinant of trastuzumab resistance in breast cancer. Cancer Cell. 2007;12:395-402.

42. Eichhorn PJ, Gili M, Scaltriti M, Serra V, Guzman M, Nijkamp W, Beijersbergen RL, Valero V, Seoane J, Bernards R, Baselga J. Phosphatidylinositol 3-kinase hyperactivation results in lapatinib resistance that is reversed by the $\mathrm{mTOR} /$ phosphatidylinositol 3-kinase inhibitor NVP-BEZ235. Cancer Res. 2008;68:9221-9230.

43. Dave B, Migliaccio I, Gutierrez MC, Wu MF, Chamness GC, Wong H, Narasanna A, Chakrabarty A, Hilsenbeck SG, Huang J, Rimawi M, Schiff R, Arteaga C, Osborne CK, Chang JC. Loss of phosphatase and tensin homolog or phosphoinositol-3 kinase activation and response to trastuzumab or lapatinib in human epidermal growth factor receptor 2-overexpressing locally advanced breast cancers. J Clin Oncol. 2011;29:166-173.

44. Razis E, Bobos M, Kotoula V, Eleftheraki AG, Kalofonos HP, Pavlakis K, Papakostas P, Aravantinos G, Rigakos G, Efstratiou I, Petraki K, Bafaloukos D, Kostopoulos I, Pectasides D, Kalogeras KT, Skarlos D, Fountzilas G. Evaluation of the association of PIK3CA mutations and PTEN loss with efficacy of trastuzumab therapy in metastatic breast cancer. Breast Cancer Res Treat. 2011;128:447-456.

45. Tsujimoto Y, Shimizu S. Another way to die: autophagic programmed cell death. Cell Death Differ. 2005;12 Suppl 2:1528-1534.

46. Bialik S, Kimchi A. Autophagy and tumor suppression: recent advances in understanding the link between autophagic cell death pathways and tumor development. Adv Exp Med Biol. 2008;615:177-200.

47. Shen S, Kepp O, Kroemer G. The end of autophagic cell death? Autophagy. 2012;8:1-3.

48. Cheng Y, Li H, Ren X, Niu T, Hait WN, Yang J. Cytoprotective effect of the elongation factor-2 kinasemediated autophagy in breast cancer cells subjected to growth factor inhibition. PLoS One. 2010;5:e9715.

49. Han W, Pan H, Chen Y, Sun J, Wang Y, Li J, Ge W, Feng L, Lin X, Wang X, Wang X, Jin H. EGFR tyrosine kinase inhibitors activate autophagy as a cytoprotective response in human lung cancer cells. PLoS One. 2011;6:e18691.

50. Li X, Fan Z. The epidermal growth factor receptor antibody cetuximab induces autophagy in cancer cells by downregulating HIF-1alpha and Bcl-2 and activating the beclin 1/hVps34 complex. Cancer Res. 2010;70:5942-5952.

51. Li X, Lu Y, Pan T, Fan Z. Roles of autophagy in cetuximabmediated cancer therapy against EGFR. Autophagy. 2010;6:1066-1077.

52. Klionsky DJ, Abdalla FC, Abeliovich H, Abraham RT, Acevedo-Arozena A, Adeli K et al. Guidelines for the use and interpretation of assays for monitoring autophagy. Autophagy. 2012;8:445-544.

53. Tanner M, Kapanen AI, Junttila T, Raheem O, Grenman S, Elo J, et al. Characterization of a novel cell line established from a patient with Herceptin-resistant breast cancer. Mol Cancer Ther 2004; 3:1585-1592.

54. Nagy P, Friedländer E, Tanner M, Kapanen AI, Carraway $\mathrm{KL}$, Isola $\mathrm{J}$, et al. Decreased accessibility and lack of activation of ErbB2 in JIMT-1, a herceptin-resistant, MUC4-expressing breast cancer cell line. Cancer Res 2005; 65:473-482.

55. Jönsson G, Staaf J, Olsson E, Heidenblad M, VallonChristersson J, Osoegawa K, et al. High-resolution genomic profiles of breast cancer cell lines assessed by tiling BAC array comparative genomic hybridization. Genes Chromosomes Cancer. 2007; 46:543-558.

56. Lenferink AE, Busse D, Flanagan WM, Yakes FM, Arteaga CL. ErbB2/neu kinase modulates cellular p27(Kip1) and cyclin D1 through multiple signaling pathways. Cancer Res. 2001;61:6583-6591.

57. Vazquez-Martin A, Colomer R, Brunet J, Menendez JA. Pharmacological blockade of fatty acid synthase (FASN) reverses acquired autoresistance to trastuzumab (Herceptin by transcriptionally inhibiting 'HER2 super-expression' occurring in high-dose trastuzumab-conditioned SKBR3/ Tzb100 breast cancer cells. Int J Oncol. 2007;31:769-776.

58. Sims D, Bursteinas B, Gao Q, Jain E, MacKay A, Mitsopoulos C, Zvelebil M. ROCK: a breast cancer functional genomics resource. Breast Cancer Res Treat. 2010;124:567-572.

59. Neve RM, Chin K, Fridlyand J, Yeh J, Baehner FL, Fevr T, Clark L, Bayani N, Coppe JP, Tong F, Speed T, Spellman PT, DeVries S, Lapuk A, Wang NJ, Kuo WL, Stilwell JL, Pinkel D, Albertson DG, Waldman FM, McCormick F, Dickson RB, Johnson MD, Lippman M, Ethier S, Gazdar A, Gray JW. A collection of breast cancer cell lines for the study of functionally distinct cancer subtypes. Cancer Cell. 2006;10:515-527.

60. Cufí S, Vazquez-Martin A, Oliveras-Ferraros C, MartinCastillo B, Vellon L, Menendez JA. Autophagy positively regulates the $\mathrm{CD} 44(+) \mathrm{CD} 24(-/$ low $)$ breast cancer stem-like phenotype. Cell Cycle. 2011;10:3871-3885.

61. Geng J, Klionsky DJ. The Atg8 and Atg12 ubiquitinlike conjugation systems in macroautophagy. 'Protein modifications: beyond the usual suspects' review series. EMBO Rep. 2008;9:859-864.

62. Tanida I. Autophagosome formation and molecular mechanism of autophagy. Antioxid Redox Signal. 2011;14:2201-2214.

63. Pyo JO, Nah J, Jung YK. Molecules and their functions in autophagy. Exp Mol Med. 2012;44:73-80.

64. Hanada T, Ohsumi Y. Structure-function relationship of Atg12, a ubiquitin-like modifier essential for autophagy. Autophagy. 2005;1:110-118. 
65. Hanada T, Noda NN, Satomi Y, Ichimura Y, Fujioka Y, Takao T, Inagaki F, Ohsumi Y. The Atg12-Atg5 conjugate has a novel E3-like activity for protein lipidation in autophagy. J Biol Chem. 2007;282:37298-37302.

66. Bass A, Sauer D, Klionsky DJ.A PCR analysis of the ubiquitin-like conjugation systems in macroautophagy. Autophagy. 2011;7:1410-1414.

67. Wong AS, Cheung ZH, Ip NY. Molecular machinery of macroautophagy and its deregulation in diseases. Biochim Biophys Acta. 2011;1812:1490-1497.

68. Yang Z, Klionsky DJ. Mammalian autophagy: core molecular machinery and signaling regulation. Curr Opin Cell Biol. 2010;22:124-131.

69. Xie Z, Klionsky DJ. Autophagosome formation: core machinery and adaptations. Nat Cell Biol. 2007;9:11021109.

70. Mariño G, López-Otín C. Autophagy: molecular mechanisms, physiological functions and relevance in human pathology. Cell Mol Life Sci. 2004;61:1439-54.

71. Maiuri MC, Tasdemir E, Criollo A, Morselli E, Vicencio JM, Carnuccio R, Kroemer G. Control of autophagy by oncogenes and tumor suppressor genes. Cell Death Differ. 2009; 16:87-93.

72. Harrison B, Kraus M, Burch L, Stevens C, Craig A, GordonWeeks P, Hupp TR. DAPK-1 binding to a linear peptide motif in MAP1B stimulates autophagy and membrane blebbing. J Biol Chem. 2008;283:999-10014.

73. Gozuacik D, Kimchi A. DAPk protein family and cancer. Autophagy. 2006;2:74-79.

74. Kiyono K, Suzuki HI, Matsuyama H, Morishita Y, Komuro A, Kano MR, Sugimoto K, Miyazono K. Autophagy is activated by TGF-beta and potentiates TGF-beta-mediated growth inhibition in human hepatocellular carcinoma cells. Cancer Res. 2009;69:8844-8852.

75. Suzuki HI, Kiyono K, Miyazono K. Regulation of autophagy by transforming growth factor- $\beta$ (TGF- $\beta$ ) signaling. Autophagy. 2010;6:645-647.

76. Al-Hajj M, Wicha MS, Benito-Hernandez A, Morrison SJ, Clarke MF. Prospective identification of tumorigenic breast cancer cells. Proc Natl Acad Sci USA 2003; 100:39833988.

77. Mani SA, Guo W, Liao MJ, Eaton EN, Ayyanan A, Zhou AY, Brooks M, Reinhard F, Zhang CC, Shipitsin M, Campbell LL, Polyak K, Brisken C, Yang J, Weinberg RA. The epithelial-mesenchymal transition generates cells with properties of stem cells. Cell. 2008;133:704-715.

78. Morel AP, Lièvre M, Thomas C, Hinkal G, Ansieau S, Puisieux A. Generation of breast cancer stem cells through epithelial-mesenchymal transition. PLoS ONE 2008; 3:2888.

79. Creighton CJ, Li X, Landis M, Dixon JM, Neumeister VM, Sjolund A, Rimm DL, Wong H, Rodriguez A, Herschkowitz JI, Fan C, Zhang X, He X, Pavlick A, Gutierrez MC, Renshaw L, Larionov AA, Faratian D,
Hilsenbeck SG, Perou CM, Lewis MT, Rosen JM, Chang JC. Residual breast cancers after conventional therapy display mesenchymal as well as tumor-initiating features. Proc Natl Acad Sci U S A. 2009;106:13820-13825.

80. Creighton CJ, Chang JC, Rosen JM. Epithelialmesenchymal transition (EMT) in tumor-initiating cells and its clinical implications in breast cancer. J Mammary Gland Biol Neoplasia 2010; 15:253-260.

81. Ouyang G, Wang Z, Fang X, Liu J, Yang CJ. Molecular signaling of the epithelial to mesenchymal transition in generating and maintaining cancer stem cells. Cell Mol Life Sci 2010; 67:2605-2618.

82. Singh A, Settleman J. EMT, cancer stem cells and drug resistance: an emerging axis of evil in the war on cancer. Oncogene 2010; 29:4741-4751.

83. Oliveras-Ferraros C, Corominas-Faja B, Cufí S, VazquezMartin A, Martin-Castillo B, Iglesias JM, López-Bonet E, Martin AG, Menendez JA. Epithelial-to-mesenchymal transition (EMT) confers primary resistance to trastuzumab (Herceptin). Cell Cycle. 2012;11:4020-4032.

84. Kahn BB, Alquier T, Carling D, Hardie DG. AMPactivated protein kinase: ancient energy gauge provides clues to modern understanding of metabolism. Cell Metab. 2005;1:15-25.

85. Hardie DG. Sensing of energy and nutrients by AMP-activated protein kinase. Am J Clin Nutr. 2011;93:891S-896S.

86. Hardie DG, Ross FA, Hawley SA. AMPK: a nutrient and energy sensor that maintains energy homeostasis. Nat Rev Mol Cell Biol. 2012;13:251-262.

87. Deberardinis RJ, Sayed N, Ditsworth D, Thompson CB. Brick by brick: metabolism and tumor cell growth. Curr Opin Genet Dev. 2008;18:54-61.

88. DeBerardinis RJ, Lum JJ, Hatzivassiliou G, Thompson CB. The biology of cancer: metabolic reprogramming fuels cell growth and proliferation. Cell Metab. 2008;7:11-20.

89. Jones RG, Thompson CB. Tumor suppressors and cell metabolism: a recipe for cancer growth. Genes Dev. 2009;23:537-548.

90. Romero-Garcia S, Lopez-Gonzalez JS, Báez-Viveros JL, Aguilar-Cazares D, Prado-Garcia H. Tumor cell metabolism: an integral view. Cancer Biol Ther. 2011;12:939-948.

91. Ward PS, Thompson CB. Metabolic reprogramming: a cancer hallmark even warburg did not anticipate. Cancer Cell. 2012;21:297-308.

92. Spector NL, Yarden Y, Smith B, Lyass L, Trusk P, Pry K, Hill JE, Xia W, Seger R, Bacus SS. Activation of AMPactivated protein kinase by human EGF receptor 2/EGF receptor tyrosine kinase inhibitor protects cardiac cells. Proc Natl Acad Sci U S A. 2007;104:10607-10612.

93. Shell SA, Lyass L, Trusk PB, Pry KJ, Wappel RL, Bacus SS. Activation of AMPK is necessary for killing cancer cells and sparing cardiac cells. Cell Cycle. 2008;7:1769- 
1775 .

94. Meley D, Bauvy C, Houben-Weerts JH, Dubbelhuis PF, Helmond MT, Codogno P, Meijer AJ. AMP-activated protein kinase and the regulation of autophagic proteolysis. J Biol Chem. 2006;281:34870-34879.

95. Ben Sahra I, Laurent K, Giuliano S, Larbret F, Ponzio G, Gounon P, Le Marchand-Brustel Y, Giorgetti-Peraldi S, Cormont M, Bertolotto C, Deckert M, Auberger P, Tanti JF, Bost F. Targeting cancer cell metabolism: the combination of metformin and 2-deoxyglucose induces p53-dependent apoptosis in prostate cancer cells. Cancer Res. 2010;70:2465-2475.

96. Ben Sahra I, Tanti JF, Bost F. The combination of metformin and 2 deoxyglucose inhibits autophagy and induces AMPK-dependent apoptosis in prostate cancer cells. Autophagy. 2010;6:670-671.

97. Vazquez-Martin A, Oliveras-Ferraros C, Cufí S, Del Barco S, Martin-Castillo B, Menendez JA. Metformin regulates breast cancer stem cell ontogeny by transcriptional regulation of the epithelial-mesenchymal transition (EMT) status. Cell Cycle. 2010;9:3807-3814.

98. Cufí S, Vazquez-Martin A, Oliveras-Ferraros C, MartinCastillo B, Joven J, Menendez JA. Metformin against TGF $\beta$-induced epithelial-to-mesenchymal transition (EMT): from cancer stem cells to aging-associated fibrosis. Cell Cycle. 2010;9:4461-4468.

99. Vazquez-Martin A, López-Bonetc E, Cufí S, OliverasFerraros C, Del Barco S, Martin-Castillo B, Menendez JA. Repositioning chloroquine and metformin to eliminate cancer stem cell traits in pre-malignant lesions. Drug Resist Updat. 2011;14:212-223.

100. Cufi S, Corominas-Faja B, Vazquez-Martin A, OliverasFerraros C, Dorca J, Bosch-Barrera J, Martin-Castillo B, Menendez JA. Metformin-induced preferential killing of breast cancer initiating CD44+CD24-/low cells is sufficient to overcome primary resistance to trastuzumab in HER2+ human breast cancer xenografts. Oncotarget. 2012;3:395398.

101. Del Barco S, Vazquez-Martin A, Cufí S, Oliveras-Ferraros C, Bosch-Barrera J, Joven J, Martin-Castillo B, Menendez JA. Metformin: multi-faceted protection against cancer. Oncotarget. 2011;2:896-917.

102. McAfee Q, Zhang Z, Samanta A, Levi SM, Ma XH, Piao S, Lynch JP, Uehara T, Sepulveda AR, Davis LE, Winkler JD, Amaravadi RK. Autophagy inhibitor Lys05 has singleagent antitumor activity and reproduces the phenotype of a genetic autophagy deficiency. Proc Natl Acad Sci U S A. 2012; 109:8253-8258.

103. Amaravadi RK, Winkler JD. Lys05: A new lysosomal autophagy inhibitor. Autophagy. 2012;8:1383-1384.

104. Liu J, Xia H, Kim M, Xu L, Li Y, Zhang L, Cai Y, Norberg HV, Zhang T, Furuya T, Jin M, Zhu Z, Wang H, Yu J, Li Y, Hao Y, Choi A, Ke H, Ma D, Yuan J. Beclin1 controls the levels of $\mathrm{p} 53$ by regulating the deubiquitination activity of USP10 and USP13. Cell. 2011;147:223-234.

105. Solomon VR, Lee H. Chloroquine and its analogs: a new promise of an old drug for effective and safe cancer therapies. Eur J Pharmacol. 2009; 625:220-233.

106. Carew JS, Kelly KR, Nawrocki ST.Autophagy as a target for cancer therapy: new developments. Cancer Manag Res. 2012;4:357-365.

107. Gorski SM, Ries J, Lum JJ. Targeting autophagy: The Achilles' heel of cancer. Autophagy. 2012;8:1279-1280.

108. Maycotte P, Aryal S, Cummings CT, Thorburn J, Morgan MJ, Thorburn A. Chloroquine sensitizes breast cancer cells to chemotherapy independent of autophagy. Autophagy. 2012;8:200-212.

109. Mancias JD, Kimmelman AC. Targeting autophagy addiction in cancer. Oncotarget. 2011;2:1302-1306.

110. Austin CD, De Mazière AM, Pisacane PI, van Dijk SM, Eigenbrot C, Sliwkowski MX, Klumperman J, Scheller RH. Endocytosis and sorting of ErbB2 and the site of action of cancer therapeutics trastuzumab and geldanamycin. Mol Biol Cell. 2004;15:5268-5282.

111. Austin CD, Wen X, Gazzard L, Nelson C, Scheller $\mathrm{RH}$, Scales SJ. Oxidizing potential of endosomes and lysosomes limits intracellular cleavage of disulfide-based antibody-drug conjugates. Proc Natl Acad Sci U S A. 2005;102:17987-17992.

112. Marx C, Held JM, Gibson BW, Benz CC. ErbB2 trafficking and degradation associated with K48 and K63 polyubiquitination. Cancer Res. 2010;70:3709-3717.

113. Paris L, Cecchetti S, Spadaro F, Abalsamo L, Lugini L, Pisanu ME, Iorio E, Natali PG, Ramoni C, Podo F. Inhibition of phosphatidylcholine-specific phospholipase $\mathrm{C}$ downregulates HER2 overexpression on plasma membrane of breast cancer cells. Breast Cancer Res. 2010;12:R27.

114. Moussay E, Kaoma T, Baginska J, Muller A, Van Moer K, Nicot N, Nazarov PV, Vallar L, Chouaib S, Berchem $\mathrm{G}$, Janji B. The acquisition of resistance to TNF $\alpha$ in breast cancer cells is associated with constitutive activation of autophagy as revealed by a transcriptome analysis using a custom microarray. Autophagy. 2011;7:760-770 